\title{
Troodos: A Giant Serpentinite Diapir
}

\author{
Roelof Dirk Schuiling \\ Institute of Geosciences, Utrecht, The Netherlands \\ E-mail: schuiling@geo.uu.nl \\ Received September 18, 2010; revised February 19, 2011; accepted April 1, 2011
}

\begin{abstract}
Troodos is a classical ophiolite complex. It is proposed that the serpentinized harzburgites that now form the top of the mountain and represent the originally lowest part of the ophiolite sequence rose as a diapir. This diapiric rise is caused by the pervasive serpentinization of a suboceanic harzburgite, due to rock-sea water interaction. The serpentinization caused a $44 \%$ expansion of the rocks. Contrary to salt diapirism, the driving force for this diapiric rise is not so much the difference in density, but the volume increase asscociated with the transformation of harzburgite into serpentinite. The overlying gabbros, sheeted dike complex and pillow lavas were pierced by this serpentinite diapir but barely deformed. Their interaction with sea water was limited to some pyroxenes in the gabbros being transformed to amphiboles, and epidotisation of some of the dikes in the sheeted dike complex. The location of steep faults in the Troodos massif is determined by the contrasting expansion behavior of different rock-types on both sides of the fault.
\end{abstract}

Keywords: Ophiolites, Seawater Interaction, Serpentinization, (Lack of) Deformation, Cyprus, Olympic Flame

\section{Introduction}

Troodos is a classical ophiolite complex, representing a slow spreading zone. Pillow lavas, sheeted dike complex, gabbros, layered dunites and mantle rocks (serpentinized harzburgites) are all represented. In its upper part there are radiolarites and even some umbers, formed by submarine exhalations, which also deposited the famous copper deposits of Cyprus. The top of Troodos Mountain is composed of pervasively serpentinized harzburgites, which represent the lowest part of the ophiolite sequence.

It is well known that serpentinites can be easily ductilely deformed under stress, like rock salt. In analogy to salt diapirism, the serpentinized harzburgites around the top of Troodos mountain on Cyprus are interpreted as a serpentinite diapir. Serpentinite diapirism has been described many times, often from fore-arc environments $[1,2]$. The volume expansion associated with serpentinization is considered to be the main driving force behind the serpentinite diapirism. In future research on ophiolite complexes this tectonic role of serpentinization should be taken into account.

\section{Observations}

The harzburgites are pervasively serpentinized. Serpenti- nization proceeds by

$$
\mathrm{Mg}_{2} \mathrm{SiO}_{4}+\mathrm{MgSiO}_{3}+2 \mathrm{H}_{2} \mathrm{O} \rightarrow \mathrm{Mg}_{3} \mathrm{Si}_{2} \mathrm{O}_{5}(\mathrm{OH})_{4}
$$

The molar volume of the serpentine on the right hand side is $108.5 \mathrm{~cm}^{3}$, whereas the sum of the volumes of olivine + enstatite is $75.3 \mathrm{~cm}^{3}$ [3]. This means that a harzburgite expands $44 \%$ during pervasive serpentinization. Even if the ratio enstatite/olivine in the original harzburgite was not exactly $1: 1$, once the conditions are in the stability field of lizardite, slight amounts of either magnesium or silica which are required for the formation of monomineralic serpentine rock will be extracted from the large volume of percolating seawater. This is commonly observed in the formation of monomineralic zones during metasomatism. In case the iron becomes oxidized to magnetite during serpentinization, one can write the reactions as follows (there is a large variation range of possible reactions, all leading to fairly similar results). The olivine will have had a composition close to $\mathrm{Mg}_{0.92} \mathrm{Fe}_{0.08} \mathrm{SiO}_{4}$, as is common in peridotites. During the oxidation of $\mathrm{FeO}$ to magnetite, possibly with an intermediate stage of ferroan brucite [4], the silica associated with the iron end-members of the olivine and enstatite will be released. This silica will react with the abundantly available magnesium in the percolating sea water to form additional serpentine, according to 
$0.04 \mathrm{Fe}_{2} \mathrm{SiO}_{4}+0.04 \mathrm{FeSiO}_{3}+0.12\left[\mathrm{Mg}^{2+}\right]+0.01 \mathrm{CO}_{2}+$ $0.22 \mathrm{H}_{2} \mathrm{O} \rightarrow 0.04 \mathrm{Fe}_{3} \mathrm{O}_{4}+0.04 \mathrm{Mg}_{3} \mathrm{Si}_{2} \mathrm{O}_{5}(\mathrm{OH})_{4}+0.01$ $\mathrm{CH}_{4}+0.24 \mathrm{H}^{+}$

If we sum up the volume changes of the solid phases in both reactions, we find that the volume change when a harzburgite is serpentinized in a large volume of hot seawater, and the iron is transformed into magnetite is almost 50\%. This is in agreement with the data presented by Jamtveit and Austrheim [5] who state "Complete serpentinization results in a solid volume increase of nearly $50 \%$ and causes a pronounced change in rheology".

As there are many variations possible, we can conclude that the associated volume change is of the order of $40 \%$ to $50 \%$. In the reaction the divalent iron is oxidized by the simultaneous reduction of $\mathrm{CO}_{2}$ and water to methane. Methane emanations are often associated with actively ongoing serpentinization. A famous example is the famous Yanartaşı (Turkish for "the rock that always burns") on the Turkish mainland, $250 \mathrm{~km}$ to the northwest of the western tip of Cyprus, where methane flames are permanently emerging from a dunite in the process of serpentinization.

\subsection{Intermezzo}

The Yanartaşı has played an important role in classical
Greek history and mythology. Nearby was the ancient Greek city of Olympos. On festive occasions the young men of the town had to run to the mountain with a torch in hand, to be lighted by the methane flames. The first man to return to Olympos with a burning torch was the winner. It is hard to believe that this is not the origin of the Olympic flame.

It also plays a central role in the myth of Bellerophon and his winged horse Pegasos. Bellerophon had to kill the chimaera, a fire-breathing dragon that was ravaging the country. After Bellerophon had spotted the dragon from his flying horse, he dived into it and drove the dragon into the ground. It is dead, but its flames are still escaping.

\subsection{Absence of Deformation}

Most rocks of the Troodos complex are undeformed, without foliation or preferred orientation. The gabbros are even explicitly designated as "isotropic gabbros", showing that their lack of tectonic imprint is obvious. Their chemical transformation is limited to local amphibolitization of their pyroxenes. The sheeted dikes and the pillow lavas are equally undeformed, having preserved even delicate glass selvages between the pillows (Figure 1).

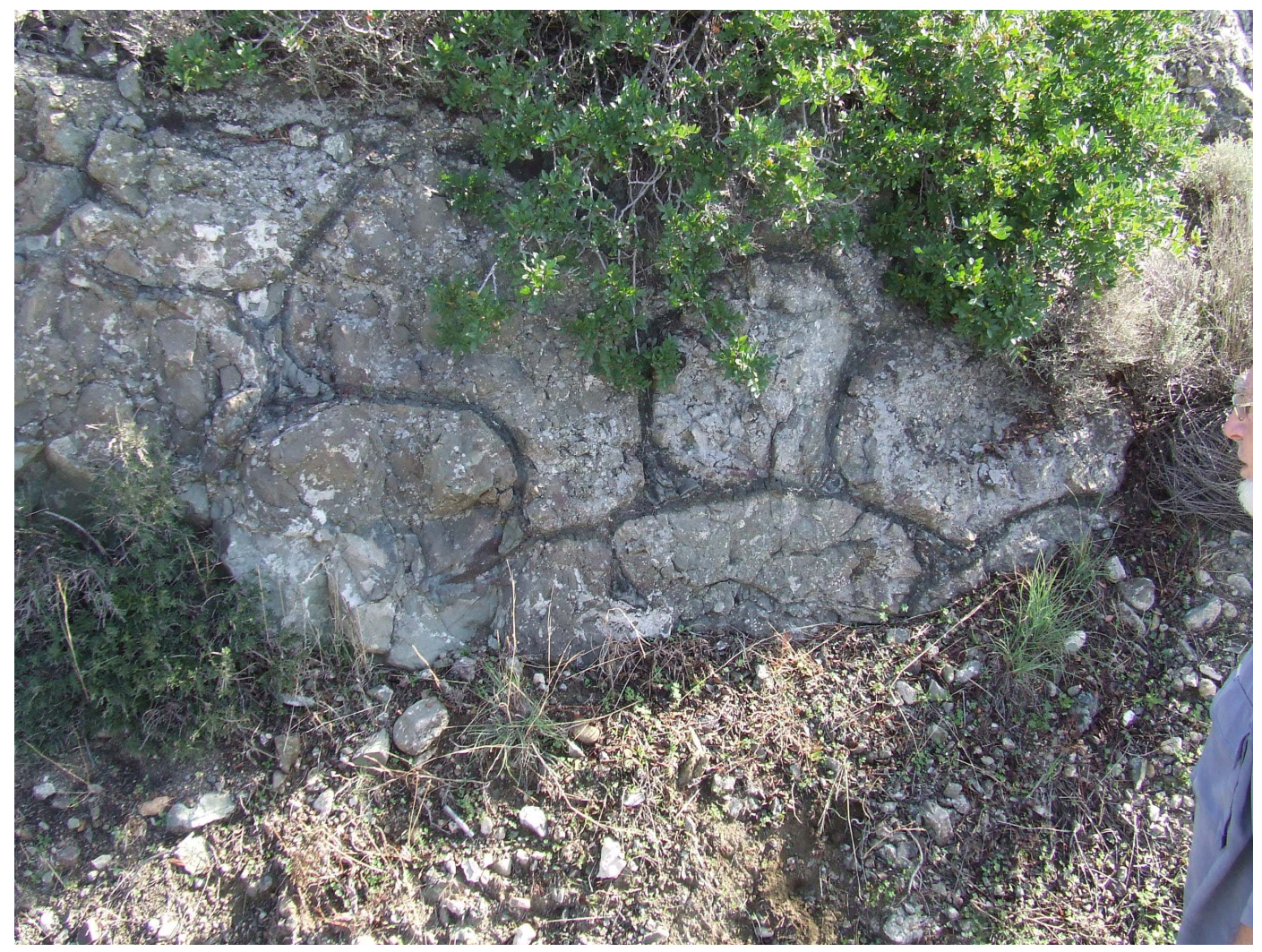

Figure 1. Pillow lavas with uncracked selvages of basaltic glass. Photo B.N.'tHart. 
The glass has remained unbroken throughout their geological history. Some of the dikes are tilted, but most are (sub-) vertical. Dunites occasionally show igneous layering marked by chromite stringers, but are undeformed.

Some steep faults crosscut the complex, separating for example the serpentinized harzburgites from gabbros. We will assign no meaning to these faults, except that the two rock masses must have moved with respect to each other.

\section{Where Does This Lead Us?}

After the spreading activity had stopped, very little movement has affected the Troodos massif since, except some tilting and occasional faulting. A similar observation is made by Gass [6], who states "The least deformed ophiolites appear to be vertically uplifted pieces of ocean floor that have not yet undergone much horizontal deformation. Two such sequences are ... and the Troodos massif in Cyprus".

Plate tectonic models for the region require large movements, but the rocks tell a different story. They show no sign of large-scale movement, and lack the internal fabric associated with tectonic transport. Yet, Troodos rises to 1952 meter asl, although the rocks that are now at the top of the mountain represent the deepest part of the ophiolitic pile. They were part of a spreading ridge at a sea depth of 2 to $3 \mathrm{~km}$.

In the absence of large-scale horizontal displacements, applying Occam's razor, "the simplest explanation is usually the best", it is proposed that these serpentinites rose vertically from the depth of the oceans to their present height.

Field evidence suggests that this vertical rise of the center of the Troodos mountain was not only accompanied by, but probably even caused by pervasive serpentinization. To explain the total uplift of the Troodos Mt. by serpentinization requires considerable seawater/rock interaction. Serpentinites probably flow similar to salt, particularly when heated to a certain extent by hydration reactions [7], so in analogy to salt diapirs it is likely that seawater/rock interaction first affected a broader area than the diapir itself, but that the serpentinized were squeezed upward through a narrower conduit. This is analogous to what happens in salt diapirs, where the salt in the diapir does not only derive from the salt that was directly underneath, but also from salt that flowed sideways towards the diapir from a broader layer of salt. Salt has a lower specific mass than the overlying sediments, and likewise the serpentinized harzburgite is also considerably lighter than the overlying ophiolitic rocks. The serpentinized harzburgite has a specific mass of appr. $2.200 \mathrm{~kg} / \mathrm{m}^{3}$, whereas the specific masses of the overly- ing rock types (gabbros, dunites, diabase dikes and pillow lavas) range between 2.800 and $3.350 \mathrm{~kg} / \mathrm{m}^{3}$. This means that even without the enormous expansion there is already a considerable force to set the diapiric movement in motion. Yet, while in salt diapirism the density differrence is the only driving force, in serpentinite diapirism the expansion plays a more important role than the density difference.

When a rock expands, it must make room for itself. In that sense it is more similar to the technology to raise parts of the land by injecting sulfuric acid into subsurface limestones. The resulting gypsum has twice the volume of the original limestone, which causes the land to be uplifted, making it safer for inundations [8]. In Germany, considerable damage to houses is associated with uplift caused by the transformation of anhydrite into gypsum. Since September 2007, numerous buildings in Staufen's Old Town have begun to exhibit large cracks that have formed due to the uplift of the substrata. The extent of the damage is considerable and there is no end to the uplift process in sight. A geochemical process called anhydrite swelling has been confirmed as the cause of these uplifts [9].

The pushing together of serpentinites that derive from different corners and slightly different thermal regimes in the suboceanic harzburgite reservoir as it undergoes serpentinization may offer an elegant solution to the remarkable $\delta \mathrm{D}$ and $\delta^{18} \mathrm{O}$ gradients observed by Nuriel et al. [10].

Intense seawater/rock interaction is also evident from many dikes that have been transformed into undeformed epidotites, from which the submarine exhalative copper deposits derive for which Cyprus is famous.

Each dike of the sheeted dike complex represents an extension equal to the thickness of that dike, but the underlying mantle must simultaneously have undergone a similar extension, providing easy access to seawater that will react rapidly with the anhydrous mantle rocks, helped by the fact that the hydration reaction is strongly exothermic [7]. The uneven thermal expansion that results may crack the rocks further, making them even more accessible to seawater interaction.

A steep fault must separate gabbros from serpentinized harzburgite, as one rock expands and rises 4 to $6 \mathrm{~km}$, whereas its neighbor does not move. Such steep faults are typical of diapiric settings. The fact that the Amianthos Fault [10], separating the serpentinized harzburgites from the adjoining gabbro dies out as soon as it leaves the contact between these two rock-types with contrasting expansion behavior is illustrative.

The diapiric rise of its central part has caused some upward bending of the sediments around the Troodos massif. Uplift continued at least to Miocene times, as 
some Messinian gypsum layers are slightly tilted, sloping away from the Troodos complex. Troodos may even still be rising today, which could indicate that even now the serpentinite has not yet reached its ultimate equilibrium position.

During its formation Troodos was probably similar to the Atlantis sea mount that rises $3 \mathrm{~km}$ above the ocean floor [11] and is also composed of serpentinized mantle rocks and gabbros, and associated with white smokers.

\section{Conclusions}

The Troodos mountain is a huge serpentinite diapir that was formed by seawater/rock interaction.

\section{References}

[1] P. Fryer and G. J. Fryer, "Origin of Nonvolcanic Seamounts in a Forearc Environment," In: B. H. Keating, P. Fryer, R. Batiza and G. W. Boelert, Eds., Seamounts, Islands, and Atolls, Geophysical Monograph Series 43, American Geophysical Union, Washington DC, 1987, pp. 61-69.

[2] G. Boillot, et al., "Ocean-Continent Boundary off the Iberian Margin: A Serpentinite Diapir West of Galicia Bank," Earth and Planetary Science Letters, Vol. 48, No. 1, 1980, pp. 23-34. doi:10.1016/0012-821X(80)90166-1

[3] R. A. Robie, et al., "Thermodynamic Properties of Minerals and Related Substances at 298.14 K and 1 Bar (105 Pascals) Pressure and at Higher Temperatures," US Geological Survey, 1978.
[4] W. Bach, et al., "Unraveling the Sequence of Serpentinization Reactions: Petrography, Mineral Chemistry and Petrophysics of Serpentinites from MAR $15^{\circ} \mathrm{N}$," Geophysical Research Letters, Vol. 33, No. 13, 2006, pp. 4-7. 10.1029/2006GL025681

[5] B. Jamtveit and H. Austhreim, "Metamorphism: The Role of Fluids," Elements, Vol. 6, No. 3, 2010, pp. 153-158. doi:10.2113/gselements.6.3.153

[6] I. G. Gass, "Origin and Emplacement of Ophiolites," Geological Society, Vol. 7, 1977, pp. 72-76. doi:10.1144/GSL.SP.1977.007.01.07

[7] R. D. Schuiling, "Serpentinization as a Possible Cause of High Heat-Flow Values in and near Oceanic Ridges," Nature, Vol. 201, No. 4921, 1964, pp. 807-808. doi: $10.1038 / 201807 \mathrm{~b} 0$

[8] R. D. Schuiling, "Geochemical Engineering; Taking Stock," Journal of Geochemical Exploration, Vol. 62, No. 1-3, 1998, pp. 1-28. doi:10.1016/S0375-6742(97)00042-3

[9] News Archive Space, "TerraSAR-X Image of the Month: Ground Uplift under Staufen's Old Town," 22 October 2009.

[10] P. Nuriel, et al., "Fault-Related Oceanic Serpentinization in the Troodos Ophiolite, Cyprus: Implications for a Fossil Oceanic Core Complex," Earth and Planetary Science Letters, Vol. 282, No. 1-4, 2009, pp. 34-46. doi:10.1016/i.epsl.2009.02.029

[11] D. S. Kelley, "From the Mantle To Microbes. The Lost City Hydrothermal Field," Oceanography, Vol. 18, No. 3, 2005, pp. 33-45. 